ROCZNIKI PEDAGOGICZNE

Tom 13(49), numer $4-2021$

DOI: http://doi.org/10.18290/rped21134.6

\author{
ANNA BŁASIAK \\ EWA DYBOWSKA
}

\title{
WZMACNIANIE REZYLIENCJI W RODZINIE - WSPÓŁCZESNĄ POTRZEBĄ
}

\section{WPROWADZENIE}

Dzisiaj mamy do czynienia z intensyfikacją przemian cywilizacyjnych, dokonujących się w każdym obszarze życia społecznego, które niejednokrotnie zaskakują i wymagają specyficznego działania na różnych płaszczyznach, także w obszarze edukacyjno-wychowawczym. Pojawiają się nowe oczekiwania, wymagania i wyzwania związane z wychowaniem najmłodszego pokolenia - z przygotowaniem na nieprzewidywalne, co wiąże się z ukształtowaniem kompetencji adaptacyjnych i dostosowawczych do „społeczeństwa ryzyka” i „nowego nieporządku świata”.

W pespektywie nowych wymagań wychowawczych uwypukla się zjawisko rezyliencji ${ }^{1}$, które może być sposobem na opanowanie „niepewnego jutra” i dostosowaniem się do funkcjonowania w coraz bardziej złożonym świecie, zwłaszcza, że wychowujemy do określonych wartości i „ku lepszemu stanowi”. Rezyliencja może być skutecznym sposobem utrzymania psychofizycznego i materialnego dobrostanu przez jednostkę i jej system rodzinny pomimo przeciwności i kryzysu. Szczególnie ważna w obszarze wychowania rodzinnego okazuje się strategia rozwijania i wzmacniania poczucia własnej skuteczności i sprawstwa oraz

Dr hab. AnNA BŁASIAK, prof. AIK - Instytut Nauk o Wychowaniu, Wydział Pedagogiczny Akademii Ignatianum w Krakowie; adres do korespondencji: ul. Kopernika 26, 31-501 Kraków; e-mail: anna.blasiak@ignatianum.edu.pl; ORCID: https://orcid.org/0000-0002-0824-2640

Dr Ewa DyвowsKa - Instytut Nauk o Wychowaniu, Wydział Pedagogiczny Akademii Ignatianum w Krakowie; adres do korespondencji: ul. Kopernika 26, 31-501 Kraków; e-mail: ewa.dybowska@ ignatianum.edu.pl

${ }^{1}$ W. Junik $(2011,2012)$ wskazała, że w języku polskim nie ma terminu, który w pełni oddawałby istotę zjawiska „resilience”. Dlatego zaproponowała, aby w naukowych publikacjach w języku polskim posługiwać się oryginalnym terminem resilience lub jego spolszczoną wersją „rezyliencja”. Autorki artykułu stosują spolszczoną wersję dla analizowanego terminu. 
pozytywnych zasobów poszczególnych członków rodziny i całego środowiska rodzinnego. Dzięki temu dzieci i rodzice stają się bardziej odporni na zagrożenia i lepiej przygotowani do przezwyciężania trudności oraz funkcjonowania w świecie realnych zagrożeń.

Celem artykułu jest naukowy namysł nad konstruktem rezyliencji w kontekście społecznej zmiany oraz ukazanie znaczenia rezyliencji dla człowieka i jego systemu rodzinnego. Postawiono problem badawczy: w jaki sposób można rozwijać i wzmacniać rezyliencję w rodzinie? Ważne będzie ukazanie roli środowiska rodzinnego w procesie kształtowania i wzmacniania rezyliencji, co dzisiaj można interpretować w kategorii potrzeb i wyzwań. Wynika to z tego, że rezyliencja sprzyja rozwojowi i funkcjonowaniu człowieka w niepewności i ustawicznie zmieniających się warunkach, a nową potrzebą w wychowaniu, wynikającą z dokonującej się zmiany społecznej, jest dostosowanie się do niepewnej przyszłości i przygotowanie się na nieprzewidywalne, pomoc w kształtowaniu człowieka do nowych wyzwań współczesności. Zaprezentowano argumenty, że rezyliencja może być istotnym konstruktem dla współczesnego człowieka oraz może być rozwijana i wzmacniana w podstawowym środowisku życia i rozwoju - rodzinie.

Badacze rezyliencji wskazują, że dzięki niej ma miejsce utrzymanie i rozwój zdrowej psychiki mimo niekorzystnych warunków życiowych, zapewnienie najbardziej optymalnego wielokierunkowego funkcjonowania jednostki (człowieka, rodziny). Jej skutkiem jest moderowanie efektu negatywnego wpływu zagrożeń i przeciwności, ochrona przed niedostosowaniem społecznym, wspieranie rozwoju, samorealizacji, strategii radzenia sobie z trudnościami oraz procesów twórczych i transformacyjnych. Staje się pomocna w odkrywaniu zasobów, sił człowieka i rodziny, wspiera kompetencje emocjonalno-społeczne. Jest też sposobem na utrzymanie dobrostanu, prowadzenia aktywnego życia w obliczu zagrożeń i zmiany (Czech-Włodarczyk, 2018; Smulczyk, 2016; Junik, 2012; Oszwa, Domagała-Zyśk, Knopik, 2017; Konaszewski, 2020).

Aktualnie doświadczany stan pandemii jest przejawem niepewności życia i nieprzewidywalności. Jest „ryzykiem wykraczającym poza ramy”, ponieważ charakteryzuje się wysokim poziomem niepewności i niesie ogromne nieodwracalne szkody. Współczesny człowiek doświadcza choroby i śmierci bliskich, silnego stresu emocjonalnego i niepokoju, licznych napięć, ciągłych zmian, sprzecznych informacji, „niewiedzy”, izolacji społecznej, osłabienia funkcji poznawczych. Ma ograniczony dostęp do opieki zdrowotnej, co w wielu przypadkach skutkuje pogorszeniem stanu zdrowia. Znikoma aktywność fizyczna i zła dieta prowadzi do obniżonej sprawności fizycznej, nadmiernej masy ciała i problemów z otyłością. Realizowana edukacja zdalna nie zawsze jest prawidłowo zorganizowana, co przyczynia się do obniżonego poziomu nauczania. Do tego dochodzą w przypadku 
młodych ludzi problemy związane z bezpieczeństwem w sieci, czy nadmiernym korzystaniem z nowych technologii. Praktycy wskazują na wzrastające zjawisko przemocy domowej. Zaciera się granica między pracą zawodową realizowaną zdalnie a życiem rodzinnym i czasem wolnym.

Pod względem metodologicznym artykuł stanowi syntetyczno-analityczny przegląd literatury oraz analizę danych zastanych istotnych dla danego problemu o zasięgu krajowym i międzynarodowym, by zrealizować założony cel oraz odpowiedzieć na postawiony problem. Dokonany wywód odwołuje się do psychologicznej i pedagogicznej koncepcji rezyliencji oraz teorii systemowego ujęcia rodziny, jak również idei sił społecznych powiązanej z teorią zasobów i sił rodziny.

\section{REZYLIENCJA - ANALIZA ZNACZEŃ \\ I KONTEKSTÓW UŻYCIA POJĘCIA}

Rezyliencja to pojęcie wielowymiarowe i multidyscyplinarne. Ma długą i różnorodną historię znaczeniową, choć termin ten zaczęto stosować w psychologii w latach 50. XX wieku (ego-resiliency J. i J. Blocków), a spopularyzowany został w latach 80. XX wieku. Do dzisiaj jest prowadzona dyskusja dotycząca problemów definicyjnych (nadal brak jest jednomyślności w tym zakresie) oraz trudności związanych z operacjonalizacją i pomiarem rezyliencji (Smulczyk, 2016). Termin ten został zapożyczony z fizyki, gdzie oznacza wysoką elastyczność, sprężystość materiałów odpornych na zniekształcenia (Czech-Włodarczyk, 2018). Etymologia słowa wskazuje na łacińskie pochodzenie, gdzie resilire oznacza odbicie, odskok, powrót do początku, uzyskanie równowagi (Sikorska, 2017). W języku polskim termin ten jest tłumaczony i można go spotkać pod określeniem prężności (N. Ogińska-Bulik, Z. Juczyński, Z. Uchnast), sprężystości (Ł. Kaczmarek, H. Sęk) odporności psychicznej (R. Opora), rezyliencji (W. Junik) i resilience (K. Ostaszewski, A. Borucka, K. Konaszewski).

Pojęcie rezyliencji ma interdyscyplinarny charakter, dlatego możemy je spotkać w naukach przyrodniczych, ekonomii, planowaniu przestrzennym, czy przede wszystkim w psychologii. W naukach społecznych ${ }^{2}$ odnosi się do dobrego funkcjonowania jednostki/grupy społecznej w niekorzystnych warunkach życiowych

\footnotetext{
${ }^{2}$ K. Konaszewski (2020) opracował koncepcję pedagogiki wrażliwej na resilience. W wąskim znaczeniu oznacza wiedzę edukacyjno-wychowawczą wspierającą przede wszystkim adaptacyjne procesy uczenia się i nauczania. Natomiast w szerokim znaczeniu to wiedza o realizacji swoistej sztuki życia pośród wyzwań; celem jest wzmacnianie ludzi poprzez procesy rozumienia samego siebie i wyjaśnianie rzeczywistości, wspieranie ich w procesach samostanowienia i podążania do rozwoju, aby w sposób zadowalający funkcjonowali w obliczu różnych wyzwań i kryzysów.
} 
i rozwojowych. Obejmuje procesy i mechanizmy, które sprzyjają pozytywnej adaptacji człowieka czy grupy.

„W zależności od sposobu opisywania, wyjaśniania, wyznaczania granic można wyróżnić różne koncepcje resilience: resilience jako cechę, jako proces i jako wynik" (Konaszewski, 2020, s. 21). Najwcześniej rezyliencję ujmowano jako cechę związaną ze zdrowiem i skutecznym radzeniem sobie z problemami życia osobistego i społecznego, jako właściwość człowieka, zdolność adaptacyjną umożliwiającą pozytywny rozwój w warunkach nasilonego, długotrwałego stresu. Wraz z rozwojem badań zaczęto rezyliencję definiować jako dynamiczny, adaptacyjny proces, który umożliwia osobie funkcjonowanie w coraz bardziej złożonym świecie, mimo doświadczanych przez nią przeciwności losu, zagrożeń lub traumatycznych przeżyć, i może się on rozpoczynać w dowolnym momencie życia. Proces ten obejmuje wzajemne oddziaływanie całego spektrum czynników ryzyka, podatności i czynników chroniących. Kolejne podejście do definiowania rezyliencji dotyczy kategorii wyniku, czyli rezultatu uwarunkowanego wieloma czynnikami o charakterze jednostkowym i środowiska, które oddziałują na siebie. Wskazane konstrukty rezyliencji, choć różnie definiowane, mają dwa elementy wspólne: przeciwności (nieszczęścia, niepowodzenia, trudności) i pozytywną adaptację (dostosowanie się) (Konaszewski, 2020; Rutkowska, 2015; Junik, 2012).

\section{CZYNNIKI CHRONIĄCE - MECHANIZMY WSPIERAJĄCE REZYLIENCJĘ W RODZINIE}

Rezyliencja jest procesem zasilanym i wspomaganym triadą czynników ochraniających, które klasyfikowane są ze względu na źródło pochodzenia jako grupa czynników: osobistych/indywidualnych, społecznych/rodzinnych, społecznych poza-rodzinnych/środowiskowych (Oszwa, Domagała-Zyśk, Knopik, 2017). Często czynniki rodzinne bywają ujmowane razem z środowiskowymi w jednej kategorii.

Czynniki chroniące to zasoby, które wspomagają człowieka/system w radzeniu sobie z działaniem czynników ryzyka (czyli sytuacje, zdarzenia, konteksty, które mogą zaburzać funkcjonowanie jednostki) lub zapobiegają ich uaktywnieniu się (Rutkowska, 2015). Czynniki chroniące, pozytywne siły, sprzyjają aktywizacji zasobów odpornościowych i pozytywnej adaptacji oraz dobremu funkcjonowaniu jednostki, mimo negatywnych doświadczeń w jej życiu (Smulczyk, 2016).

Rozbudowaną koncepcję indywidualnych czynników chroniących (5 kategorii) zaproponował K. Kumpfer. Do pierwszej kategorii czynników zaliczył czynniki duchowe i motywacyjne: np. marzenia, cele i dążenie do nich, poczucie sensu życia, religijność, unikatowość, wiarę w siebie, nadzieję i optymizm, wewnętrzną 
kontrolę. Drugą grupę stanowią zasoby poznawcze, do których należy: inteligencja, poczucie własnej wartości, kreatywność, osiągnięcia szkolne czy zawodowe, zdolność do przewidywania następstw swoich działań i zachowań, umiejętność wglądu w sytuację i jej ocenę, świadomość posiadanych zasobów i ograniczeń. Kolejną kategorię stanowią w tej koncepcji kompetencje społeczne, spośród których istotne są umiejętności komunikacyjne, asertywność, androgyniczność (zdolność do modyfikowania swojego zachowania jako kobiecego lub męskiego w zależności od okoliczności), zdolność rozwiązywania problemów, budowania intymnych relacji. Posiadanie pozytywnych relacji z innymi, bliskie związki sprzyjają lepszemu radzeniu sobie w sytuacjach trudnych, ponadto zwiększa się prawdopodobieństwo uzyskania wsparcia i pomocy od innych. Stabilność emocjonalna i umiejętność kierowania swoimi emocjami typu złość czy gniew, radość czy zadowolenie zaliczone zostały do następnej grupy czynników chroniących w tej koncepcji. Nie bez znaczenia jest także posiadanie poczucia humoru oraz dystansu do własnej osoby. Wskazuje się, że osoba rezylientna potrafi w sytuacji trudnej panować nad swoimi emocjami, kontroluje je i wyraża w sposób społecznie akceptowany, nie krzywdząc innych i siebie. Ostatnią kategorię stanowią czynniki powiązane ze zdrowiem fizycznym, obejmują atrakcyjność fizyczną, dobre samopoczucie zdrowotne, ale także aktywny styl życia i atrakcyjny wygląd, co wpływa na samoocenę i zwiększoną motywację do aktywności (Rutkowska, 2015; Konaszewski, 2020).

Z kolei badania G. Granta, P. Ramcharana, M. Flynn (2007) wykazały, że w obszarze czynników chroniących indywidualnych należy uwzględniać i troszczyć się o: pozytywną postawę, optymizm wobec trudności oraz pozytywny obraz siebie, ponadto ważna jest niezależność i poczucie autonomii oraz entuzjazm, otwartość poznawcza. Istotny jest też umiarkowany poziom napięcia jako czynnik motywacyjny, jak również poczucie sprawczości oraz potrzeba poszukiwania celu, sensu i znaczenia.

Badania nad rezyliencją ujawniły także, że istnieją właściwości niezależne od jednostki, a które różnicują sposób przystosowania się do trudnej sytuacji. Dotyczy to płci i temperamentu (Rutkowska, 2015).

Z kolei do chroniących czynników rodzinnych zalicza się przede wszystkim dobre relacje i bliskie więzi, rodzinę, która daje dziecku okazję do rozwijania swoich zainteresowań i konstruktywnego spędzania czasu wolnego, odpowiedni/ wysoki status socjoekonomiczny rodziny (wykształcenie, miejsce zamieszkania, styl życia, dochody) (Rutkowiak, 2015). Inne klasyfikacje, obok bliskich i zadowalających relacji rodzinnych, wskazują na spójność rodziny i przeżywanie pozytywnych emocji w rodzinie oraz na świadomość miłości i wsparcia od rodzica w sytuacji trudnej oraz gruntowne wychowanie, bezpieczny styl przywiązania oraz 
zadowalające warunki ekonomiczne rodziny (Oszwa, Domagała-Zyśk, Knopik, 2017; Smulczyk, 2016).

Natomiast w obszarze kategorii czynników chroniących środowiskowych podkreśla się przede wszystkim bezpieczne sąsiedztwo, posiadanie przyjaciół wykazujących pozytywne wzorce społeczne oraz mentora, ponadto obecność instytucji pomocowych, działalność na rzecz innych, dostęp do opieki zdrowotnej. Istotna jest też świadomość potencjalnej gotowości do pomocy osób z dalszego otoczenia, czy również realna możliwość zwrócenia się o pomoc do osób spoza rodziny, poczucie przynależności do grupy odniesienia, na której można polegać. Autorzy podkreślają, że czynniki chroniące $\mathrm{z}$ dwóch ostatnich grup pozostają w ścisłym związku z czynnikami indywidualnymi (Rutkowiak, 2015; Oszwa, Domagała-Zyśk, Knopik, 2017; Smulczyk, 2016).

\section{RODZINNE KONTEKSTY REZYLIENCJI - IDEA REZYLIENTNEJ RODZINY}

W literaturze dotyczącej rezyliencji pojawiła się także kategoria rezylientnej rodziny obok rezylientnej osoby. Idea dotyczy rodziny pielęgnującej i wzbogacającej wzajemne relacje i więzi, która koncentruje się na mocnych stronach i jej zasobach, rozwija swoje możliwości, buduje szczęście oparte na zaangażowaniu i wzajemnej współpracy członków, zwiększa umiejętności w radzeniu sobie ze stresem w przyszłości. Przy czym zasadnicza definicja rezyliencji w odniesieniu do rodziny została zaproponowana przez H. i M. McCubbin (za: Konaszewski, 2020, s. 126), gdzie ujęto rezyliencję rodziny ,jako cechy, wymiary lub właściwości, które pomagają rodzinie uniknąć rozpadu w obliczu zmian i przystosować się w sytuacjach kryzysowych. Są to cechy, właściwości, cechy systemu rodzinnego, które umożliwiają mu zachowanie ustalonych wzorców funkcjonowania po zakwestionowaniu czynników ryzyka i stawieniu im czoła. Jest to także zdolność rodziny do szybkiego powrotu do zdrowia po nieszczęściu, urazie lub przejściowym zdarzeniu, powodującym zmiany w funkcjonowaniu rodziny lub podjęcie wyzwań do zmiany". Zatem rezyliencja rodziny obejmuje potencjalne zasoby systemu rodzinnego, które ułatwiają adaptację i regenerację. Każda rodzina ma potencjał, by uzyskać rezyliencję i jest to dynamiczny proces, unikalny dla danej rodziny, w której można zidentyfikować pewne wspólne zasoby i mocne strony, mogące pomóc rodzinie w radzeniu sobie z poważnymi przeciwnościami, które stają się katalizatorem rozwoju rodziny (Konaszewski, 2020).

Początkowo, jak to zostało wskazane, koncentrowano się na kwestiach związanych z funkcjonowaniem rezylientnej jednostki, jednak z czasem przeniesiono 
rozważania do szerszych systemów, w tym rodziny. Badania nad rezyliencją rodziny rozwinęły się wokół dwóch głównych modeli teoretycznych. Pierwszy obejmuje model resilience adaptacji i przystosowania rodziny (dwie fazy) i został zaproponowany przez H. i M. McCubbin. Drugi tzw. model ram resilience rodziny w perspektywie systemowej zaproponowany przez F. Walsh (2016), gdzie autorka ujmuje rezyliencję jako umiejętność wytrzymania i odbicia się od przeciwności, akcentując nacisk na wzmocnienie i większą zaradność, obejmując rozwój rodziny w zakresie indywidualnym i grupowym (Konaszewski, 2020). Systemowe teorie rodziny dostarczyły podstaw teoretycznych do zajmowania się rodziną jako całością. Takie ujęcie rodziny umożliwiło mówienie o rezyliencji relacyjnej (relationship resilience), czyli o rezyliencji jako konstrukcie teoretycznym na poziomie rodziny (Lechowska, 2014). Poniżej zostanie bliżej zaprezentowany model F. Walsh.

\section{MODEL RAM RESILIENCE RODZINY F. WALSH - CECHY I WARTOŚCI REZYLIENTNEJ RODZINY}

Koncepcja rezyliencji rodziny opracowana przez F. Walsh zawiera zasadniczą zmianę w spojrzeniu na rodzinę. Ma bowiem miejsce odejście od koncentracji na deficytach rodziny i przejście w kierunku stojących przed nią wyzwań. Przy założeniu o nieodłącznym potencjale systemu rodzinnego do zdrowienia oraz pozytywnego rozwoju opartego na przeciwnościach. Autorka uważa, że każda rodzina, bez względu na napotykane trudności i przeciwności, ma potencjał, aby uzyskać rezyliencję w odpowiedzi na kryzys. Rezyliencja z jednej strony umożliwia adaptację lub kompetencję w radzeniu sobie z przeciwnościami, a z drugiej daje możliwość pozytywnego rozwoju i transformacji, które są swoistą odpowiedzią na doświadczane trudności (Lechowska, 2014).

F. Walsh odnosi rezyliencję rodziny „do tych kluczowych procesów, które umożliwiają rodzinie efektywniejsze radzenie sobie i wzmacnianie się w efekcie kryzysów lub długotrwałych stresów, pochodzących czy to z wnętrza rodziny, czy też spoza niej" (Lechowska, 2014, s. 555-556). Ponadto w tym ujęciu podkreśla się też rolę diady rodzicielskiej, która wiąże się z obszerną siecią powiązań, identyfikując potencjalne zasoby dla indywidualnej rezyliencji w najbliższej i dalszej rodzinie (Konaszewski, 2020).

Na podstawie dokonanych analiz i badań naukowych F. Walsh zidentyfikowała fundamentalne procesy dla rezyliencji rodziny. Procesy te obejmują zjawiska zmniejszające ryzyko, a sprzyjające zdrowieniu i wzrostowi po wydarzeniu kryzysowym oraz dodające rodzinie siłę do tego, by przezwyciężyć długotrwałe 
trudności i problemy. W ten sposób zostały wskazane właściwości rodzin rezylientnych. W koncepcji tej zostały uwzględnione wartość i zasoby rodziny, które pozostają w synergicznej interakcji, wzajemnie się wzmacniają, a dotyczą trzech zasadniczych obszarów funkcjonowania rodziny w różnych systemach i na przestrzeni czasów. Pierwszy obejmuje systemy przekonań rodzinnych opartych na określonych wartościach i odnosi się do trzech następujących wymiarów (Lechowska, 2014; Konaszewski, 2020; Walsh, 2012, Walsh, 2016):

1. Nadawanie znaczeń przeciwnościom, co odpowiada relacyjnemu ujęciu rezyliencji, ponieważ dobrze funkcjonujące rodziny traktują kryzys, trudności jako wspólne wyzwanie oraz normalizują dystres i ujmują go w kontekście, wówczas problemy rodziny stają się możliwe do zrozumienia w odniesieniu do niepomyślnych okoliczności. W tym obszarze cechą jest również poczucie koherencji rodziny oraz facylitująca ocena, która odnosi się do wyjaśniania tego, co się zdarzyło przez atrybucje przyczynowe lub wyjaśniające, ponadto patrzenie z nadzieją w przyszłość.

2. Pozytywne spojrzenie na świat, co przejawia się w nadziei i w optymistycznym nastawieniu oraz przekonaniu, że przeciwności zostaną pokonane. Nadzieja stanowi źródło energii i wzmacnia podejmowane wysiłki, by pokonać przeciwności. Ta właściwość wiąże się też z odwagą i wspieraniem siebie, dostrzeganiem mocnych stron i koncentracji na potencjale. To z kolei - w ujęciu autorki - prowadzi do zmniejszenia poczucia bezradności i porażki, wzrostu dumy i zaufania, zachęca do podejmowania wysiłku, buduje zaufanie rodziny do samej siebie i kształtuje nowe kompetencje dzięki doświadczaniu własnych możliwości. Ważnym elementem tego wymiaru jest też aktywna inicjatywa i wytrwałość, co prowadzi do przejawiania przez rodzinę ufności, że zrobi wszystko, co jest w jej mocy i będzie wspierać działania swoich członków w pokonywaniu przeciwności. Ponadto kluczowe jest zrobienie wszystkiego, co możliwe oraz tolerowanie niepewności, akceptacja tego, czego nie da się zmienić. Jest to możliwe, gdy rodzina zna swoje zasoby i koncentruje się na tym, by funkcjonować optymalnie w kontekście przeciwności i wyzwań.

3. Transcendencja i duchowość opiera się na szerszych wartościach i celach wykraczających poza bezpośrednie życie rodziny. Wymiar duchowości dotyczy wiary, praktyki kontemplacyjnej, wspólnoty oraz związków z naturą. Autorka wykazała, że wartości duchowe sprzyjają rezyliencji, a rytuały i świętowanie ułatwiają przejście przez znaczące sytuacje. Do tego wymiaru włączyła F. Walsh czynnik inspiracji, który jest powiązany z dostrzeganiem możliwości, marzeniami życiowymi, kreatywną ekspresją oraz czynnik przemiany powiązany z uczeniem się, zmianą i wzrostem wynikającymi z przeciwności. 
Druga właściwość rodzin rezylientnych dotyczy wzorców organizacyjnych rodziny, które przejawiają się przede wszystkim w silnych więziach organizacyjnych, w stosowaniu strategii radzenia sobie z problemami. O tej właściwości decydują następujące czynniki (Lechowska, 2014; Konaszewski, 2020; Walsh, 2012, Walsh, 2016):

1. Elastyczność, która obejmuje otwartość na adaptacyjne zmiany, zdolność do reorganizacji i przystosowania się do nowych warunków po kryzysie oraz stabilność przeciwdziałająca zniszczeniu, bo równoważącą, umożliwiającą kontynuację życia codziennego rodzinie i pielęgnowanie rytuałów, zwyczajów, które dają poczucie ciągłości, pewności i przewidywalności. Ponadto efektywnemu funkcjonowaniu rodziny i dobrostanowi dzieci sprzyja autorytatywne zarządzanie - pewne i elastyczne oraz współpracujący system rodzicielski.

2. Relacje i związki, wzajemne wsparcie, współpraca i zaangażowanie wzmacniają rezyliencję, podobnie respektowanie indywidualnych potrzeb i różnic oraz naprawa błędów i krzywd.

3. Zasoby społeczne i ekonomiczne rodziny dotyczą w pierwszej kolejności krewnych, sieci relacji społecznych, mentorów i modeli mogących dostarczyć socjalnego i emocjonalnego wsparcia oraz budowania bezpieczeństwa finansowego, równoważenie napięć praca - rodzina, w dalszej kolejności ważne są wspierające instytucje oraz struktury i programy w miejscu pracy, placówkach edukacyjnych i opieki, innych systemach społecznych.

Ostatnia właściwość rezyliencji rodziny w tej koncepcji dotyczy procesów komunikacyjnych i rozwiązywania problemów, obejmuje następujące elementy (Lechowska, 2014; Konaszewski, 2020; Walsh, 2012, Walsh, 2016):

1. Jasne i spójne komunikaty - dla rodziny ważną kwestią jest wyjaśnianie sprzecznych informacji, możliwość wyrażania własnych oczekiwań oraz dążenie do prawdy.

2. Otwarta ekspresja emocjonalna obejmująca dzielenie się bolesnymi przeżyciami, empatyczną wrażliwość i tolerowanie różnic. Jednak ważne też jest znalezienie przez rodzinę obszarów przyjemności, przynoszących wytchnienie i ulgę oraz źródeł odnawiających energię i podnoszących rodzinę i jej członków na duchu (np. świętowanie urodzin).

3. Współpraca przy rozwiązywaniu problemów wszystkich członków rodziny powiązana jest z pomysłowością i kreatywnością oraz wspólnym podejmowaniem decyzji, sprawiedliwymi negocjacjami rodzinnymi, koncentracją na celach, podejmowaniem konkretnych działań, uczeniu się na błędach, bo to wszystko sprzyja rezyliencji. Ważna staje się tutaj również postawa proaktywna wobec kryzysu polegająca na byciu przygotowanym na wyzwanie, rozważnym planowaniu i prewencji. 


\section{WZMACNIANIE I KSZTAŁTOWANIE REZYLIENCJI W ŚRODOWISKU RODZINNYM - IMPLIKACJE PEDAGOGICZNE}

F. Walsh (2006) rozumienie rezyliencji rodziny umieszcza w ogólnej debacie na temat definiowania zdrowej rodziny i wskazywania cech zdrowej rodziny. Obala ona dwa funkcjonujące - jej zdaniem - mity. Pierwszy mit dotyczy tego, że zdrowa (funkcjonalna) rodzina jest pozbawiona problemów. Drugi mit dotyczy uniwersalnej idei zdrowej rodziny, gdyż takie podejście zubaża - jej zdaniem różnorodność modeli życia rodzinnego współcześnie. F. Walsh (2006) postrzega rodzinę jako wielość stylów i form funkcjonowania życia rodzinnego. Zakłada, że nie ma jednego modelu rodziny, który pasuje do wszystkich rodzin i ich sytuacji. Wobec powyższego, aby wzmacniać procesy rezyliencji w rodzinie należy porzucić przekonanie, że rodziny prawidłowe nie mają problemów. W codzienności życia rodziny pojawiają się bowiem częściej lub rzadziej sytuacje ekspozycji na znaczne ryzyko. Sposób poradzenia sobie z nimi stanowi o poziomie rezyliencji w rodzinie, na którą składają się kompetencje poszczególnych członków rodziny czy podsystemów rodzinnych.

Istotnym elementem, który wydaje się być punktem wyjścia, aby tworzyć $\mathrm{w}$ życiu rodzinnym przestrzeń dla rozwoju rezyliencji, to przyjęcie i akceptacja tezy, że przeciwności, wydarzenia krytyczne i sytuacje kryzysowe są normalnymi sytuacjami życiowymi, które nie powinny być źródłem wstydu, poczucia winy, czy stygmatyzacji. Problemy i przesilenia życiowe powinny być traktowane jako okazja do nauki, rozwoju i zmiany poprzez odkrywanie nowych filarów rozwoju. Rezyliencja umożliwia integrowanie niekorzystnych doświadczeń do doświadczenia życiowego (Walsh, 2012, Cyrulnik, 2015).

W rezylientnej rodzinie kryzys (normatywny, sytuacyjny) i stres wymagają sięgnięcia do wewnętrznych i środowiskowych zasobów rodziny w celu wypracowania nowych sposobów jej funkcjonowania. Fundamentem i podstawą kształtowania rezyliencji w rodzinie jest funkcjonalna diada małżeńska (Boczkowska, 2020, Walsh, 2016). Troska o relację małżeńską tworzy wokół dzieci i dla dzieci bezpieczną przestrzeń (głównie emocjonalnie) rozwoju i wzrastania. To rodzice nadają kształt codzienności życia rodzinnego i od nich w dużej mierze zależy, na ile w przestrzeni rodziny będzie miejsce na wzmacnianie, wspieranie i kształtowanie rezyliencji. W bezpiecznym otoczeniu możliwa jest koncentracja na mocnych stronach rodziny, bowiem każda rodzina posiada własny niepowtarzalny potencjał rozwojowy wypływający z zasobów zarówno indywidualnych członków rodziny jak i zasobów rodziny jako całego systemu. Wzmacnianie rezyliencji rodziny to przenoszenie akcentów w obliczu przeciwności z problemów na możliwości (Walsh, 2016). 
Kształtowaniu i wzmacnianiu rezyliencji w rodzinie sprzyja niewątpliwie zwracanie uwagi na poszanowanie godności wszystkich członków rodziny oraz wzajemne okazywanie sobie szacunku poprzez używanie języka pełnego szacunku. W codzienności życia rodzinnego rodzice poprzez modelowanie właściwej atmosfery umożliwiają bezpośrednią i bezpieczną przestrzeń do dzielenia się trudnościami, bólem i obawami. Wzajemne relacje pozwalające na okazywanie współczucia i empatyczna komunikacja stanowią wartość, która kształtuje procesy rezyliencji. Okazywane są one głównie poprzez afirmowanie pozytywnego nastawienia (Walsh, 2012).

Troską rodziców, którzy chcą poszerzać kompetencje rezyliencji swojej rodziny, winno być: szukanie jedności i harmonii w rodzinie (nazywanie problemów i natychmiastowe podejmowanie rozwiązywania konfliktów); praktykowanie bezpośredniej, szczerej i konkretnej komunikacji w rodzinie; dawnie przestrzeni do nazywania oraz okazywania uczuć i emocji; przyzwalanie na przeżywanie każdych emocji i trudnych, i przyjemnych; umiejętne (rozsądne) wydawanie pieniędzy; wspólne spędzanie czasu przez członków rodziny (posiłki, wykonywanie prac domowych, codzienne aktywności, wspólny odpoczynek, wspólne rozrywki - przez to tworzenie więzi i pogłębianie kompetencji poznawczych i społecznych dzieci); kojąca obecność; niepozostawianie samego członka rodziny w obliczu trudności, czy nagłej sytuacji; pielęgnowanie rutynowych aktywności i rytuałów rodzinnych; zapewnianie członkom rodziny poczucia bezpiecznej przynależności; usprawnianie kompetencji wychowawczych rodziców; zauważanie, nazywanie i komunikowanie mocnych stron obok słabych punktów i ograniczeń; dostrzeganie i tworzenie klimatu na pielęgnowanie talentów i rozwijanie zainteresowań; korzystanie z zasobów krewnych, społeczności lokalnej, czy zasobów osobowych w obliczu wyzwań (Walsh, 2012). Rezylientna rodzina kształtuje rezylientne dziecko, które wobec zagrożenia swojego dobrostanu będzie potrafiło wykazać się pozytywną adaptacją do nowych okoliczności. Rezylientne dziecko to dziecko, które jest wspierane oraz otrzymuje narzędzia, których potrzebuje do wzrastania i rozwoju w swoim środowisku rodzinnym (Coyle, 2011).

Poziom rezyliencji rodziny w perspektywie procesu zależy od czasu trwania niekorzystnej sytuacji, z którą rodzina musi się zmierzyć. Znaczenie ma także to, w jakim momencie cyklu życia rodzinnego jest dana rodzina (normatywne wyzwania lub nienormatywne zdarzenia) oraz z jakich zasobów wsparcia społecznego może korzystać rodzina w danej sytuacji.

Zjawisko rezyliencji rodziny wydaje się jedną z możliwych odpowiedzi na pytanie o to, dlaczego funkcjonowanie części rodzin jest stabilne wobec przewlekłych, stresujących zdarzeń, a funkcjonowanie innej części rodziny wobec podobnych zdarzeń zostaje zaburzone (Boczkowska, 2020). Rezyliencja nie jest 
wrodzoną i stabilną cechą systemu rodzinnego. Jak to jest zakładane w artykule, rezyliencja jest procesem, który dokonuje się przechodząc od koncentracji na deficytach i trudnościach do koncentracji na czynnikach chroniących. Rozwija się $\mathrm{w}$ zetknięciu z trudnymi doświadczeniami, niesprzyjającymi sytuacjami oraz kryzysami normatywnymi i kryzysami sytuacyjnymi. Rodzina oraz jej członkowie wzmacniają swoją rezyliencję korzystając z zasobów, do których mają dostęp (Kulesza, 2017). Spojrzenie na rodzinę z perspektywy rezyliencji pozwala widzieć kryzysy, stresy i wyzwania rodziny jako możliwość wspierania zdrowia i wzrostu rodziny (Black, Lobo, 2008). Należy także pamiętać, że procesy optymalnego funkcjonowania rodziny i dobrego samopoczucia jej członków zmieniają się w czasie wraz z pojawianiem się wyzwań i przechodzeniem na kolejne etapy cyklu życia rodzinnego (Walsh, 2016). W związku z tym rezyliencja jest takim procesem, który umożliwia ową optymalizację i komfort funkcjonowania rodziny.

\section{ZAKOŃCZENIE}

Kształtowanie rezyliencji staje się dzisiaj jednym z kluczowych zadań wychowania, w tym także wychowania rodzinnego. Ma ono prowadzić do optymalnego wielokierunkowego funkcjonowania współczesnego człowieka w złożonym i zmiennym świecie, w którym jednostka doświadcza „odbijania się” od trudnych sytuacji. Za kluczowy obszar rodzinnych oddziaływań wychowawczych dotyczących rezyliencji należy uznać mechanizmy i czynniki chroniące, zasoby odpornościowe i adaptacyjne, określone wartości i potencjalności jednostkowe i systemowe rodziny. Źródłem procesów rezyliencji mogą być pozytywne kompetencje społeczno-emocjonalne i poznawcze, cechy osobowościowe, stan zdrowia oraz procesy motywacyjne, które będą służyć twórczemu radzeniu sobie z przeciwnościami oraz budowaniu satysfakcjonujących relacji z innymi.

\section{BIBLIOGRAFIA}

Black, K., Lobo, M. A. (2008). Conceptual Review of Family Resilience Factors. Journal of Family Nursing, 14,1 (February), 33-55.

Boczkowska, M. (2020). Resilience rodziny - geneza koncepcji, główne pojęcia, kierunki badań. Niepetnosprawność. Dyskursy pedagogiki specjalnej, 37, 40-55.

Coyle, James P. (2011). Resilient Families Help Make Resilient Children. Journal of Family Strengths; $11,1$. 
Cyrulnik, B. (2015). Opiekunowie i proces rezyliencji. Studia Poradoznawcze/Journal of Counsellogy, 4. 121-130.

Czech-WŁodarczyK, C. (2018). Potencjał społeczny i pedagogiczny koncepcji social resilience w erze neoliberalnej. Forum Pedagogiczne, 1, 183-194.

Grant, G., Ramcharan, P., Flynn, M. (2007). Resilience in families with children and adult members with intellectual disabilities: Tracing elements of a psycho-social model. Journal of Applied Research in Intellectual Disabilities, 20, 563-575.

JunIK, W. (2011). Zjawisko rezyliencji - wybrane problemy metodologiczne. W: W. JunIK (red.). Resilience. Teoria-Badania-Praktyka (47-55). Warszawa: Wydawnictwo Edukacyjne Parpamedia.

JuNIK, W. (2012). Teoretyczne i empiryczne podstawy wzmacniania rezyliencji (resilience) u dzieci z rodzin z problemem alkoholowym. Dziecko krzywdzone, 3(40), 27-45.

Konaszewski, K. (2020). Pedagogika wrażliwa na resilience. Studium teoretyczno-empiryczne. Kraków: Impuls.

KulesZa, M. (2017). Rodzinne zasoby w pedagogice społecznej i praktyce pedagogicznej. Warszawa: Difin.

Lechowska, B. (2014). Pozytywna psychologia rodziny - w teorii i praktyce. W: I. JANICKA, H. LiBERSKa (red.), Psychologia rodziny (537-565). Warszawa: PWN.

Oszwa, U., Domagala-Zyśk, E., Knopik, T. (2017). Zasoby odpornościowe uczniów w środkowym wieku szkolnym a ryzyko niedostosowania społecznego. Ruch Pedagogiczny, 1, 91-103.

Rutkowska, M. (2015). Rezyliencja jako interdyscyplinarna kategoria analityczna i jej zastosowanie w pedagogice. Studia i Badania Naukowe, 9,1, 29-46.

SikorsKa, I. (2017). Odporność psychiczna w ujęciu psychologii pozytywnej: edukacja i terapia przez przygodę. Psychoterapia, 2(181), 75-86.

SmulczyK, M. (2016). Resilience a edukacja. Rola fenomenu skutecznej adaptacji w osiągnięciach szkolnych. Forum Oświatowe, 28(2), 203-222.

Walsh, F. (2006). Strengthening family resilience (2nd ed.). New York: Guilford Press.

Walsh, F. (2012). Family Resilience: Strengths Forged Through Adversity. In: F. WALSh (ed.), Normal Family Processes: Growing Diversity and Complexity (4th ed.) (399-427). New York: Guilford Press.

WaLSH, F. (2016). Strengthening family resilience (3rd ed.). New York: Guilford Press.

\section{WZMACNIANIE REZYLIENCJI W RODZINIE - WSPÓŁCZESNĄ POTRZEBĄ}

\section{StresZCZeNie}

Zjawisko rezyliencji stanowi przedmiot zainteresowań wielu dyscyplin naukowych, w tym także pedagogiki. Celem artykułu był naukowy namysł nad konstruktem rezyliencji w kontekście społecznej zmiany i nowych potrzeb w wychowaniu (rodzinnym) oraz ukazanie znaczenia rezyliencji dla człowieka i jego systemu rodzinnego. Przedstawiono koncepcję rezyliencji i rezylientnej rodziny, wskazując na etymologię nazwy, mechanizmy tego zjawiska i jego związki z środowiskiem rodzinnym, gdzie dokonuje się proces rozwijania i wzmacniania rezyliencji. Zaprezentowano argumenty, że rezyliencja może być istotnym konstruktem dla dzieci i ich rodziców, by byli bardziej odporni na zagrożenia i lepiej przygotowani do przezwyciężania trudności oraz optymalnego funkcjono- 
wania $\mathrm{w}$ świecie permanentnej zmiany i budowania satysfakcjonujących relacji międzyludzkich. Proces wspierania rezyliencji można zatem traktować jako obszar rozwoju osoby i rodziny. Tekst zamykają implikacje pedagogiczne, które zawierają wytyczne dotyczące budowania i wzmacniania rezyliencji w rodzinie.

Słowa kluczowe: rezyliencja/resilience; idea rezylientnej rodziny; rezyliencja rodziny; czynniki chroniące; zasoby rodziny; wychowanie rodzinne.

\title{
STRENGTHENING RESILIENCE IN THE FAMILY - A CONTEMPORARY NEED
}

\begin{abstract}
SUMmary
The phenomenon of resilience is the subject of interest to many scientific disciplines, including pedagogy. The aim of the article was a scientific reflection on the construct of resilience in the context of social change and new needs in (family) upbringing as well as the importance of resilience for person and his family system. The concept of resilience and resilient family is presented, pointing to the etymology of the name, mechanisms of this phenomenon and its relations with the family environment, where the process of developing and strengthening resilience takes place. Arguments were presented that resilience could be an important construct for children and their parents to be more resistant to threats and better prepared to overcome difficulties. And also that they should be prepared for optimal functioning in the world of permanent change and building satisfying interpersonal relationships. The process of supporting resilience can be treated as an area of development of the person and the family. The text ends with pedagogical implications that provide guidelines for building and strengthening family resilience.
\end{abstract}

Keywords: resilience; the idea of a resilient family; family resilience; protective factors; family resources; family upbringing. 